Nipawin, Sask. (through spruce muskezs and jackpine ridges on both sides of Saskatchewan River within a radius of 4 miles of Nipawin). - Dec. 26; Bricht and sunny; temp. around zero. Goshawk, 1; Spruce Grouse, 1; Ruffed Grouse, 2; Nillow Ptarmican, 9; Great Horned Owl, 3; Hairy Hoodpecker, 2; Downy Woodnecker, 3; Canada Jay, 7; Blue JaJ, 11; Magnie, 4; Black-capped Chickadee, 23; Hudsonian Chickadee, 9; Golden-crowned Kinjlet, 5 (no details-ED.); Bohemian Waxwing, 28; EnIish Sparrow, 43; Evening Grosbeak, 14; Pine Grosbeak, 8; Redpol1, 271. Total, 18 species, 444 individuals.-PH. G. STREET.

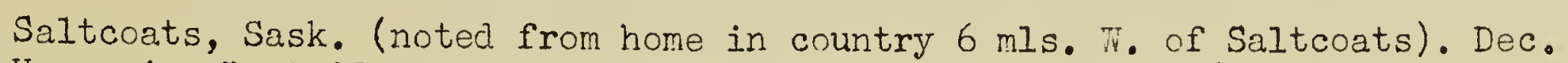
26. Hungarian Partridge, 10; Snowy OwI, I; Snow Bunting, 150 (est.). Total, (excluding English Sparrows) 3 species, approximately 161 individuals.-FRANK BAINES.

Saltcoats, Sask. (farm 3 miles E. of Saltcoats). Dec. 31; 3:00 to 5:00 r.m. Calm; slightly overcast. One observer, 3 miles, 2 hours. Ruffed Grouse, 2 ; Sharp-tailed Grouse, 6; Saw-whet Ow1, I (Specimen shot for positive identity; it is now beind stuffed); Black-capped Chickadee, 1; Enclish Sparrow, 15; Magpie, 1; Snow Bunting, 50 (est.). Total, 7 species, approximately 176 individuals.JIM ROGERSON.

Scott, Sask. (open prairie country some 30 miles south of the park belt). Jan. 1. Hungarian Partride, 9; English Sparrow, numerous; Bohemian Waxwing, 11. Total, 3 species, over 20 individuals. Several Snowy Owls and a Great Horned OwI seen during December. Prairie Chickens have not been seen since summer of 1940.F. ROUSE.

Sheho, Sask. (farm 6 miles $N$. of Sheho). Day between Dec. 25 and Jan. 1. Ruffed Grouse, I; Sharp-tailed Grouse, 5; Hungarian Partridee, 9; Hairy Woodpecker, I; American Magpie, 2; Black-capped Chickadee, 5; English Sparrow, numerous; Pine Grosbeak, 5; Rednol1, 30; Snow Buntin;, 44. Total, 10 species, over 102 individuals. Other birds noted in December: Goshawk, Great Horned OwI, Snowy Owl, Downy Woodpecker, Northern Shrike, Bohemian Waxwings. A Western Meadowlark has been wintering on the farm of a neighbor.-MM. NIVEN.

Skull Creek, Sask. (near Piarot, Sask.). Census of bird life seen during Xmas week, 1942, while goine about farm work. Amounts listed for each species are the most individuals seen during one day. Golden Eajle, 1; Prairie Falcon, 1; Ruffed Grouse, 2; Sharp-tailed Grouse, 11; Huncarian Partridge, 9; Great Horned CwI, 2; Downy Hoodpecker, 2; Western Horned Lark, 16; American Magpie, 15; Blackcappea Chickadee, 3; Bohemian Taxwing, 6; Northern Shrike, 1; English Sparrow, 27; Pine Grosbeak, 4; Redpoll, 22; Western Tree Sparrow, 2; Snow Bunting, 450 (est.). Total, 17 species, 574 individuals.-STEVE A. MANN.

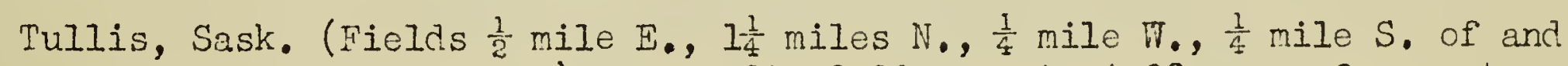
includin the hamlet of Tuliis). Dec. 27; $9: 30 \mathrm{a.m}$. to 4:00 p.m. Overcast; about $8 \mathrm{in}$. snow, with drifts as deep as 30". Wind, licht $\mathrm{E}$, at first, by 1:00 F.m. moderate S.E.; temp. $25^{\circ}$ at start, $29^{\circ}$ at return. One observer afoot. Total hours afield, 6r; 6 miles covered. Goshawk, 2; Pin-tailed Grouse (Sharptailed or Pinnated?-ED.), 5; Hungarian Partridge, 24; Snowy Owl, 1; Short-eared Ow 1, I; Northern Shrike, 1; English Sparrow, 175 (est.); Nestern Meadowlark, 1; (this is a winter resident, seen nearly every day around the yard since Dec. 12) Redpol1, 5; Snow Bunting, 25 (est.). Total, 10 species, 240 individuals.J. FRANCIS ROY. 
Yorkton, Sask. (area 15 miles in diameter with Yorkton as center).-Dec. 27; 10:00 a.m. to $5: 30 \mathrm{r} . \mathrm{m}$. Clear, bright day; stron wind from the south-east; only a thin covering of snow on the fields, abnormally licht for this time of year; temp. $-5^{\circ}$ at start, $5^{\circ}$ at $2: 00$ p.m., and $-10^{\circ}$ at finish. 9 observers in 7 groups. Total party hours afield, 11 ( 4 by car and 7 on foot); total party miles, $77 \frac{1}{2}$ ( 64

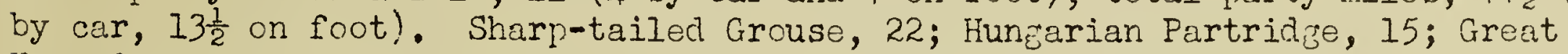
Horned CwI, 1; Downy Woodpecker, 2; American Magpie, 2; Black-capped Chickadee, 19: Bohemian Waxwing, 43; English Sparrow, 188 (est.); Redpoll, 35 (est.); Snow Bunting, 426 (est.). Total, 10 species, approximately 753 individuals. No Grosbeaks noted so far this winter. Snowy Owls have been common for the past two months, but they have now left this district. Snow Buntings vere probably so abundant due to the scarcity of snow, leaving a good food supply available. VERNON BARNES, BROTHER CLARENCE, DR. C.J. HOUSTON, DR. S. C. HOUSTON, C. STUART HOUSTON, ETHEL LLOYD, MRS. I.M. PRIESTLY, MICHAEL PRIFSTIY, JIM ROGERSON. (MEmbe:..: Yorkton Natural History Society).

\section{BOOKS TO BUY}

Two books published in 1942 which should be in the possession of every outof-door enthusiast in Saskatchewan, are "Wild Flowers of the Prairie Provinces," by Elizabeth Burnett Flock, well-known naturalist of Regina, and "The Stone Age on the Prairies" by W.G. Orchard, First President, Saskatchewan Archaelogical Society.

Mirs. Flock's book includes all the more common flowers of the West, listed al hhabetically under their popular names. Each flower is vividly described in a few telling sentences and illustrated by a characteristic pen and ink drawing by the author's husband, J.H. Flock. In addition the book contains several chapters of zeneral botanical interest and some beautiful photographs taken by Dick Bird. The price is seventy-five cents. Mrs. Flock's book has already roceived a warm welcome from nature lovers.

"The Stone Age on the Prairies," which appeared more recently, is just the book that many of us have been wanting on this subject. It gives valuable and interesting information regarding the ancient tocls to be found on the western plains and seventy full pase plates of hundreds of "Indian" relics from Mr. Orchard's own personal collection and other sources. In it Mr. Orchard also correlates what is known of the stone AEe on this continent, with the same long period of human history in other parts of the world. The Bibliography at the end of this small volume will be nost useful to those who wish to do more extensive reading $r$ sturly. "Thi Stone Age on the Prairies" sells for \$1.25 and, like Mrs. Flock's flower book, is published by School Aids Publishing Company, Regina.

\section{CONSERVATION STAMPS}

The first set in a series of Conservation Stamps to be brought out by the Science Association, University of Alberta, to raise funds for the investication of problems of wild life, are now on sale. In a letter received from Prof. $\mathrm{Im}$. Rowan, of Edmonton, he points out that huge sums of money have been raised in the United States through the sale of such stamps and that, although the present moment does not seem a very auspicious time to launch this scheme in Canada, many wild life problems which have a direct bearinj on our economic life have, due to the war, assumed a new importance. The first set depicts five common eame birds and it is planned to bring out new sets annually, so that in time a complete set of attractive pictures of Canadian game birds and animals will be offered. The stamps sell for twenty-five cents each or one dollar for the set of five, and it is hoped all interested in the conservation of our wild life will support this project. 